\title{
An evaluation of vocational high schools in Indonesia: A comparison between four-year and three-year programs
}

\author{
$*^{1}$ Soenarto; ${ }^{2} \nmid$ Muhammad Mustaghfirin Amin; ${ }^{3}$ Kumaidi \\ *Faculty of Engineering, Universitas Negeri Yogyakarta \\ Jl. Colombo No. 1, Depok, Sleman 55281, Yogyakarta, Indonesia \\ *Email: soenarto@uny.ac.id
}

Submitted: 28 November 2017 | Revised: 15 December 2017 | Accepted: 22 December 2017

\begin{abstract}
The research aimed to gain insights into the quality of four-year program vocational high school (VHS) in Indonesia compared to four-year program VHS. This research was conducted based on the school graduate standard, business sector and industrial sector (or Dunia Usaha dan Dunia Industri (DUDI)) - or the performance of the graduates and alumni (the graduates' satisfaction). The research was conducted using Discrepancy Evaluation Model using 16 VHSs (eight four-year program VHSs and eight three-year program VHSs). The result shows that from the standpoint of the school, the graduates of the four-year program VHS are higher in quality than those of the three-year program VHS. The four-year program VHS graduates are more qualified in seven aspects: teamwork, discipline, tenacity, theoretical knowledge, confidence, creativity, and leadership. Meanwhile, using DUDI standpoint, the four-year program VHS graduates are also higher in quality than the three-year program VHS graduates. In addition, the four-year program VHS graduates are better in the quality of their discipline, tenacity, theoretical knowledge, practical skills, confidence, carefulness, creativity, and leadership. The four-year program VHS graduates have a higher level of satisfaction in terms of income than the three-year program VHS graduates. The higher quality of the four-year program VHS graduates has resulted from longer duration of the internship program (PKL) that provides them with reliable experience and skills concerning work-related problem-solving activities.
\end{abstract}

Keywords: vocational high school, graduates, four-year program, three-year program

\section{How to cite item:}

Soenarto, S., Amin, M., \& Kumaidi, K. (2017). An evaluation of vocational high schools in Indonesia: A comparison between four-year and three-year programs. REiD (Research and Evaluation in Education), 3(2), 106-113. doi:http://dx.doi.org/10.21831/reid.v3i2.17077

\section{Introduction}

Education institution is a human resource production house with the managerial competency related to human resource and other related resources. Thus, it is the duty of education institutions to keep the process of improvement going and to produce graduates who fulfill the needs of the society. The society needs evolve as time changes and in alignment with the changes of circumstances. As
Asean Free Trade Area (AFTA) and Asean Economic Society (MEA) were put into effect in 2003 and in 2015 respectively, the demand of business sector and industry sector (dunia usaba dan dunia industri or DUDI) for innovative and creative workforce is on the rise. On the other hand, free competition in the open market has made the distribution of goods, services, capital and market-ready skilled labor even more dynamic. To survive under such circumstances, Indonesia has to prepare itself 
for upcoming chances and challenges in global market. Alisjahbana (2014) states that in the free trade era, from the standpoint of population, manpower and human resource, Indonesia has to pay more attention to three things: (1) keeping the demographic momentum, (2) improving the participation of manpower, and (3) improving the manpower productivity.

The afore-mentioned action of keeping demographic momentum is an action of keeping the advantage of Indonesian demography conducted by pushing the fertility rate and driving migration. Migration is an effective strategy to keep the economic growth. The demographic momentum as the foundation of Indonesian economic strength has to be followed by the effort to improve the manpower participation by nurturing flexible and efficient working climate and driving the participation of women in improving the national economy. The area of manpower participation is not the only area in need of improvement in Indonesia. Improvement is also needed in the area of manpower productivity, which can be a competitive advantadge that is able to improve the competitive edge of manpower in open market.

Vocational high school (VHS - or SMK (Sekolah Menengah Kejuruan) is one of the education institutions responsible for producing skilled workers with the ability to adapt to the changes in the need of the society as the effect of the dynamic international economy with the support of Indonesian demographic bonus. VHS can be a powerful weapon in improving manpower participation and productivity by taking advantages of education processes. Pardjono, Sugiyono, and Budiyono (2015) state that vocational education cannot be removed from existing workforce development'. Under the same light, in their research, Ramayani, Aimon, and Anis (2012) conclude that Indonesian government has to support the efforts made to improve manpower productivity by producing policy that focuses on education and health and providing more fund in the area related to human resource building.

In the Law No. 20 of 2003 of Republic of Indonesia concerning National Education System, VHS is defined as the education institution responsible for preparing students to work in certain fields of work. Dewey (1916) argues that 'a vocation means nothing but such a direction of the life activities as renders them perceptibly significant to a person, because of the consequences they accomplish, and also usefull to his assocoate.' Moreover, Thompson (1973) argues that vocational education improves students' skills that eventually will improve their productivity. VHSs then play an important role in determining the competitive edge of Indonesian manpower by providing ready-to-work and high quality workers for national and also international needs. As stated by Komariah (2010), vocational high school is an education institution responsible to prepare students for labor market and nation-building effort.

Prior to 1970, vocational high school and regular high school have the same study duration: three years. In 1970, as stipulated in through the First PELITA (Five-Year Building, or Pembangunan Lima Tabun in Indonesian term) Program, Indonesian government built eight four-year program engineering vocational high schools under the banner of 'Proyek Perintis Sekolab Teknologi Menengah Pembangunan' ('Development Engineering High School Initiative Project'). In 1974, Indonesian government built four more four-year program vocational high schools - this time with agriculture as the concentration. The goal of this project is to prepare industrial technicians or workers with engineering skill possessing (1) initiative attitude, (2) ability to work and love the work, and (3) ability to understand, manage, and implement the ideas of engineers from upper level and to provide guidance to the technical workers from lower levels. The four-year program is expected to provide supports for vocational high schools in producing skilled workers with competitive edge. All of the goals of four-year program vocational high schools are in national education standard, specifically the standards for the graduates. In the Regulation of the Minister of Education and Culture No. 20 of 2016, the competence standard of the graduates (Standar Kompetensi Lulusan/SKL) is the formula of qualification criteria for graduates, which are achieved upon the completion of a series of programs and education in the area of attitude, knowledge, and skills. 
In order to be able to achieve the goals of the Development Engineering High School Initiative Project - which is now known as four-year program vocational high schools the Directorate of Vocational High School Administration focuses on the improvement of curiculum, learning and teaching process, and evaluation process. To take everything one step further, the Directorate also focuses on the improvement of teacher professionalism and builds cooperation with parties involved in business sector and industrial sector (DUDI). However, there were doubts related to the effectiveness of four-year program vocational high school as The National Statistics Board (Badan Pusat Statistik/BPS) released data related to the number of unemployment in Indonesia in 2014. The data show that there were 2.179 million unemployed graduates of vocational high schools, which is $15.15 \%$ of the total number of unemployment in Indonesia for above-15-year-old workforce. The number is an accumulation of all unemployed graduates of four-year program vocational high schools and the graduates of three-year program vocational high schools. There were no distinction made between the graduates of four-year program vocational high schools and those of three-year program vocational high schools in the data presented by BPS although both of them do not follow the same education process. This phenomenon then made us wonder about the quality of the graduates of both programs and the differences. Table 1 shows the number of open unemployment with VHS education.

Table 1. Vocational high school graduate unemployment data in 2011-2014

\begin{tabular}{cc}
\hline Year & Total Number \\
\hline 2011 & $2,270,873$ \\
2012 & $2,085,474$ \\
2013 & $2,122,850$ \\
2104 & $2,179,886$ \\
\hline
\end{tabular}

The questions related to the worth or merit of four goals of the four-year program VHSs can only be answered through evaluation. Stufflebeam and Shinkfield (1984) define evaluation as 'systematic assessment of the worth or merit of some objects'. In this case, evaluation is conducted to define the worth or merit of the goals of four-year program vocational high schools. Stufflebeam, Madaus, and Kellaghan (2000) state that the process of evaluation should not be alien to the process of comparing. The evaluation of the worth or merit of the four-year program VHSs is conducted by comparing the competence of the graduates of both programs. The competence of the graduates is measured with the standards set by schools of origin as the provider of education services, the standards of DUDI (in terms of the performance of the graduates) as the employer of the graduates, and the personal standard of the graduates (level of satisfaction) related to their jobs.

\section{Method}

The goal of this evaluative research was to gain insights into the quality of education provided in both programs (three-year program and four-year program) of vocational high schools. The method applied in this research was Discrepancy Evaluation Model (DEM) developed by Provus. The Discrepancy Evaluation Model identifies discrepancy between the standards used as the basis of assessment and the performance in reality (Kaufman \& Susan, 1982, p. 127). This research used three-year program vocational high schools' graduates as the basis of assessment. The performance of the graduates of the three-year program vocational high school was set to be the basis or standards of assessment because it was the basis of the innovation that was known later as four-year program vocational high school. Inovation in this case is the production of something better than the existing product or program.

This research was conducted in eight three-year program VHSs and eight four-year program VHSs. All of the selected four-year program VHSs were part of the early fouryear program initiative. On the other hand, all of the selected three-year program VHSs were selected based on the similarities with the selected four-year program VHSs in terms of the area of the school location. The respondents included all parties involved in the management of the vocational high schools, such as (1) head master, (2) vice head master, (3) 
head of skill programs, (4) labor market coordinator, (5) guidance and counseling coordinator, (6) alumni, and (7) business sector and industrial sector. Table 2 shows detailed information about the respondents involved in the research.

Table 2. Research respondents

\begin{tabular}{|c|c|c|c|c|}
\hline No & $\begin{array}{l}\text { Research } \\
\text { Subjects }\end{array}$ & $\begin{array}{c}\text { four- } \\
\text { year } \\
\text { program }\end{array}$ & $\begin{array}{l}\text { three- } \\
\text { year } \\
\text { program }\end{array}$ & Total \\
\hline 1 & Head Master & 8 & 8 & 16 \\
\hline 2 & $\begin{array}{l}\text { Vice Head } \\
\text { Master }\end{array}$ & 32 & 32 & 64 \\
\hline 3 & $\begin{array}{l}\text { Head of Skill } \\
\text { Program }\end{array}$ & 40 & 40 & 80 \\
\hline 4 & $\begin{array}{l}\text { Special Labor } \\
\text { Market } \\
\text { Coordinator }\end{array}$ & 8 & 8 & 16 \\
\hline 5 & $\begin{array}{l}\text { Guidance } \\
\text { and } \\
\text { Counseling } \\
\text { Coordinator }\end{array}$ & 8 & 8 & 16 \\
\hline 6 & Alumni & 40 & 40 & 80 \\
\hline 7 & DUDI & 40 & 40 & 80 \\
\hline & Total & 176 & 176 & 176 \\
\hline
\end{tabular}

The research data were collected using questionnaire, observation, interview and documentation. The questionnaire in the data collection process was distributed to reach the opinions from schools and parties in DUDI about the competence of the graduates from both programs. In addition, the distribution of the questionnaire was also conducted to gain insights into the level of satisfaction of the graduates related to their jobs. The result of the validity test using a questionnaire showed that the instrument used was capable of measuring the data validly. The instrument reliability estimation shows that the questionnaire had the reliability coefficient as much as 0.83 which can be categorized as reliable. In collecting the supporting data related to the graduates, this research used not only a questionnaire but also observation, interview and documentation. The validity of the interview guide and observation guide was tested by experts via expert judgement.

In order to make the data fit to be presented in the form of tables and diagrams, the collected data from various instruments were processed through tabulation and analysis process using the descriptive statistics. In this step, the qualitative data were projected as a support for quantitative descriptive findings.

\section{Findings and Discussion}

The result of the data analysis on the competence, performance, and level of satisfaction of the graduates of the four-year program vocational high schools in comparison with that of the graduates of the three-year program vocational high schools is described as follows.

\section{The Graduates' Competence}

There are 11 aspects studied in this research, including team-work, discipline, ethics, tenacity, theoretical knowledge, practical skill, confidence, carefulness, creativity, sense of responsibility, and leadership. Figure 1 shows the competence of the graduates of four-year program and three-year program vocational high schoosl from the standpoint of school.

\section{The Competence of Vocational High School Graduates}

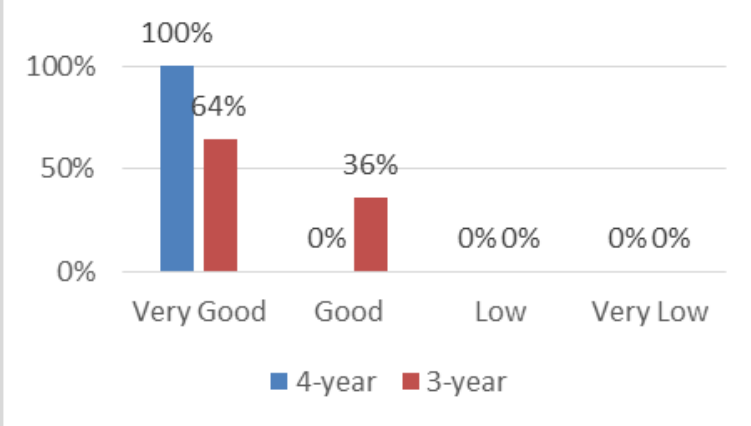

Figure 1. The competence of vocational high school graduates from the standpoint of school

Upon the analysis on the above-mentioned aspects, from the standpoint of school - represented by head masters and vice head masters - all of the graduates of four-year program vocational high schools possess 'very good' competence. This result is better than the result for graduates of three-year program vocational high schools in which only $64 \%$ of them are in 'very good' category and the rest $(36 \%)$ are in 'good' category. 


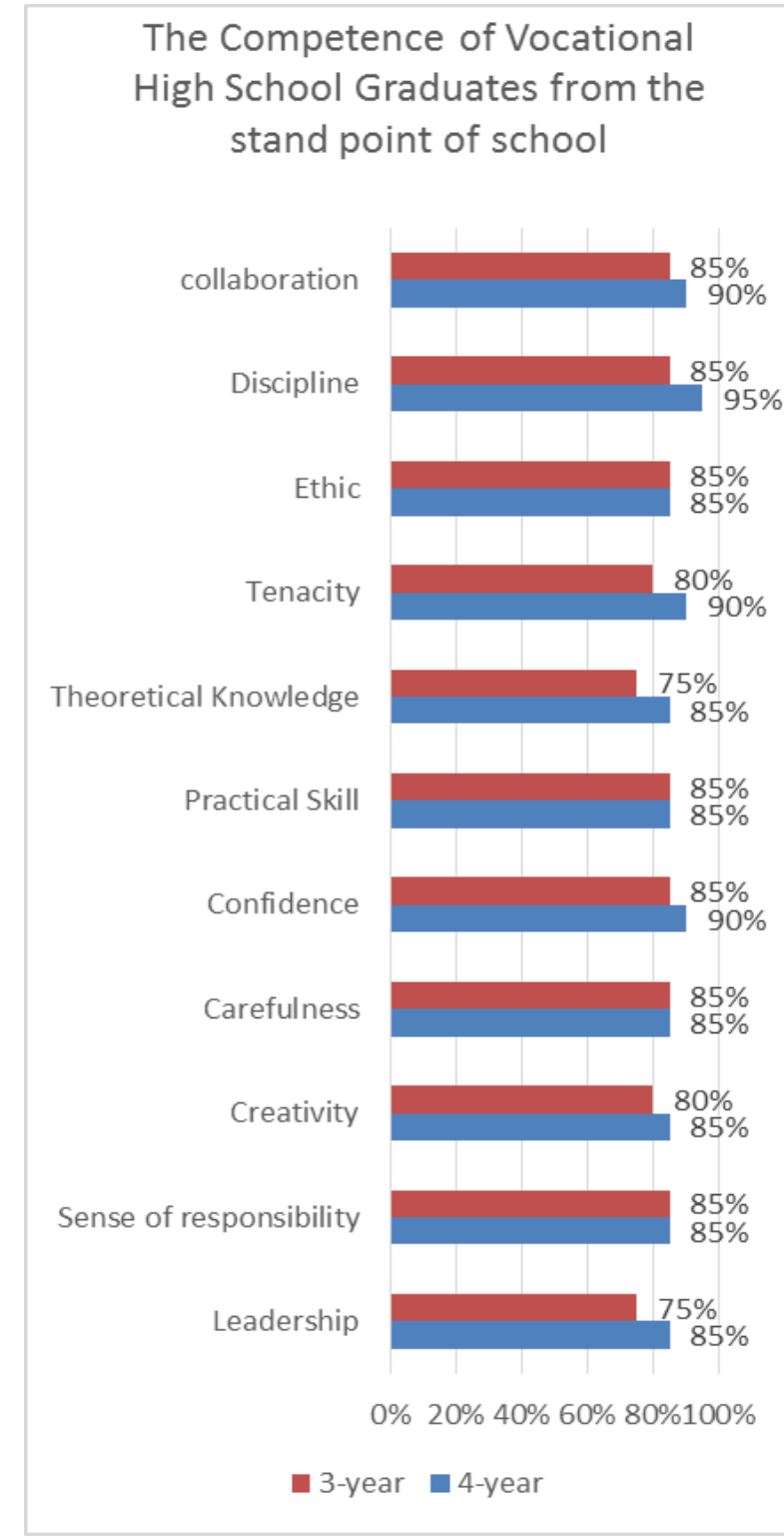

Figure 2. Aspects of competence of vocational high school graduates

The result of the assessment on all of the aspects shows that the graduates of fouryear program vocational high schools are better in seven out of eleven assessed aspects (teamwork, discipline, tenacity, theoretical knowledge, confidence, creativity, and leadership). On the other four aspects, the competence of the graduates from both programs are in the same level. The superiority of the graduates of the four-year program vocational high schools on the seven aspects resulted from their rich experienced gained in a longer internship program (or Praktik Kerja Lapangan (PKL) in Indonesian term). This longer internship program facilitated the students of four- year program vocational high schools with proficient time for in-class knowledge internalization. In addition, the longer internship program made the students more experienced in problem-solving activities in the real daily work. The superiority of the four-year program vocational high school graduates in the seven aspects made them more competent at the business world. Figure 2 shows the competence of the graduates of both programs in every measured aspect.

The Performance of the Graduates

In this research, the performance of the graduates from both programs is also analyzed from the standpoint of business sector and industrial sector (DUDI), specifically their aspects of competence. There are 11 aspects measured, including teamwork, discipline, ethic, tenacity, theoretical knowledge, practical skills, confidence, carefulness, creativity, sense of responsibility, and leadership. Figure 3 shows the comparison in terms of performance of the graduates from both programs.

\section{The Performance of Vocational High School Graduates}

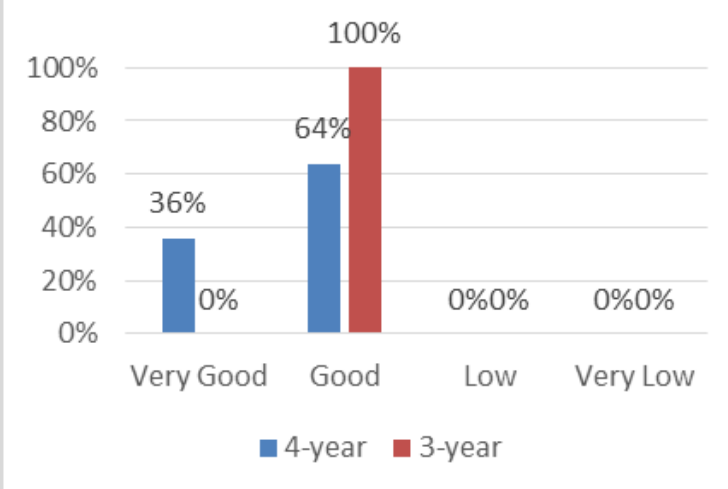

Figure 3. The performance of vocational high school graduates

The research result shows that $36 \%$ of the four-year program vocational high school graduates are in 'very good' category, whereas $64 \%$ of them are in 'good' category. The overall performance of the graduates of four-year program VHSs is better than that of the graduates of three-year program VHSs since all of the graduates of three-year program VHSs are in 'good' category . 


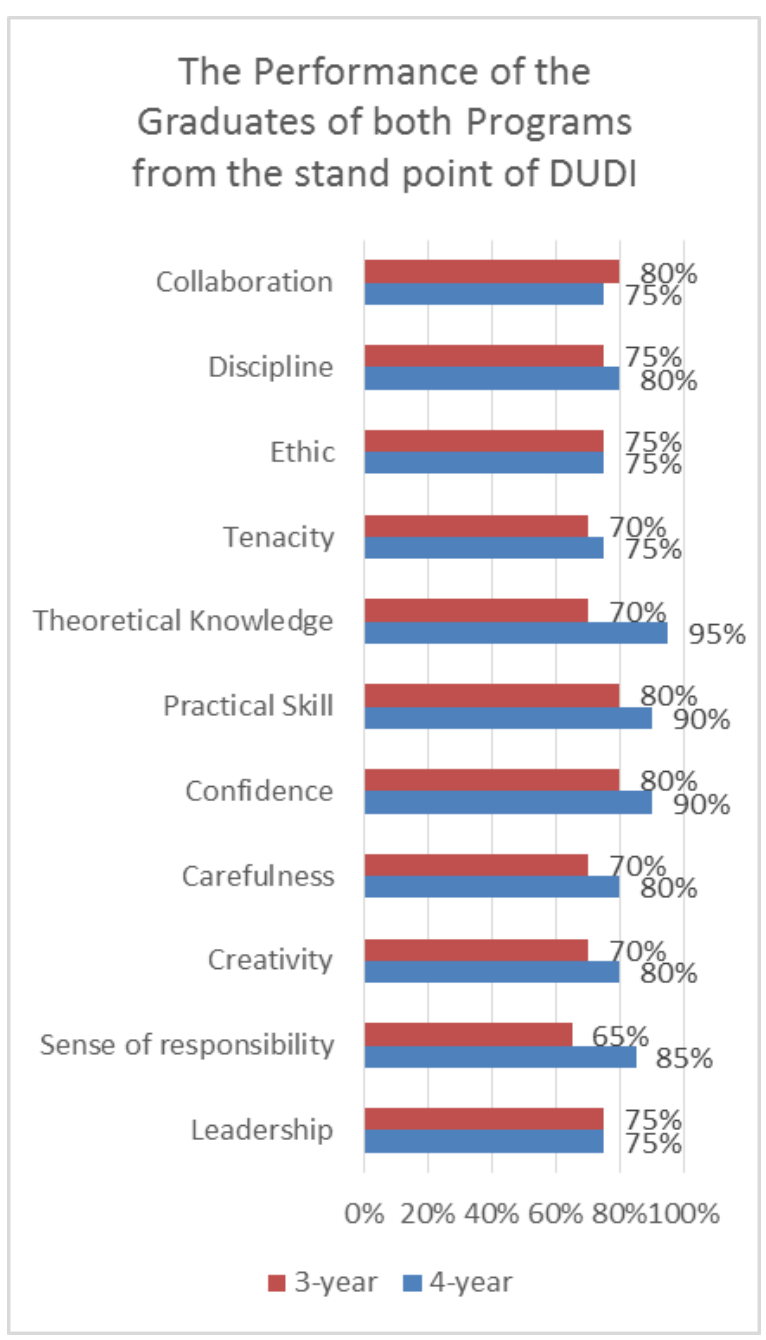

Figure 4. The performance of the graduates from the standpoint of DUDI

According to the statement of the employers or DUDI, the four-year program vocational high school graduates show superiority in eight aspects in terms of performance. They are superior in eight aspects $72.72 \%$ of total aspects studied - including discipline, tenacity, theoretical skill, practical skill, confidence, carefulness, creativity, and also leadership (see Figure 4). As in the competence analysis from the standpoint of the schools, the superiority in these aspects is resulted from the longer internship programs which provide the students with richer and reliable experience. However, there is something new and intriguing in this competence analysis from the standpoint of DUDI. In the aspect of teamwork, the graduates of the four-year program vocational high schools are inferior to that of the three-year program vocational high schools. This is driven by the fact that the graduates of the four-year program vocational high school have the ability to accomplish tasks individually since they are equipped with higher level of competence and experience.

\section{The Satisfaction of the Graduates}

The satisfaction of the graduates is an accumulation the graduates' personal opinion about their jobs. There are nine aspects studied from this standpoint: income, working atmosphere, relationship with supervisors, relationship with co-workers, intention to get another job, working satisfaction, working facilities, working environment, and health insurance. The data of the satisfaction level of the graduates related to their jobs were collected by distributing questionnaires to the graduates of vocational high schools.

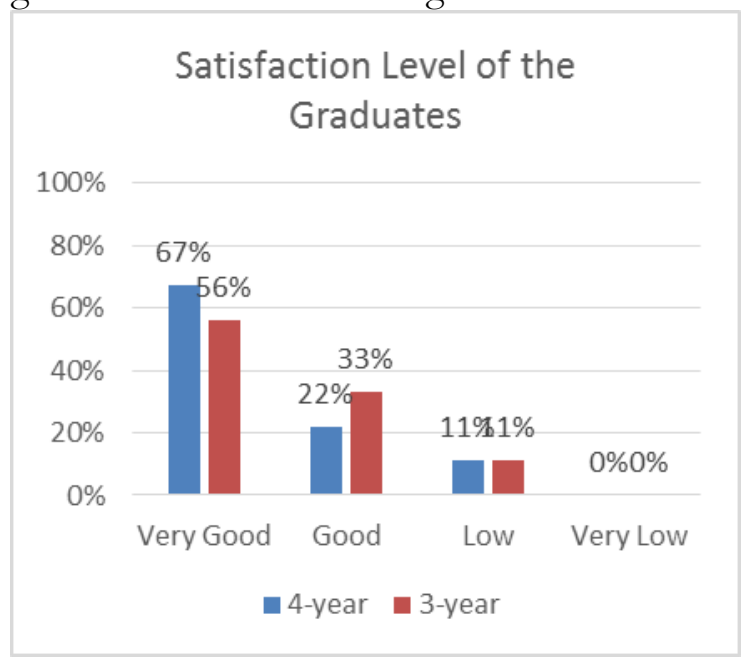

Figure 5. Satisfaction level of the graduates

Figure 5 shows the satisfaction level of the graduates of the both programs. The data show that $67 \%$ of the graduates of four-year program vocational high schools express 'very good' level of satisfaction toward their jobs. There are $22 \%$ of them who express 'good' satisfaction and $11 \%$ of them are in 'low' category. The level of satisfaction of the four-year program vocational high school graduates is higher than the level of satisfaction of the three-year program vocational high school graduates. There are $56 \%$ of the three-year program vocational high school graduates who express 'very good' level of satisfaction toward their jobs. As many as 33\% of them are in 'good' category and $11 \%$ of them are in 
'low' category. The most staggering difference is found in the aspect of income; the data show that the monthly income of the graduates of four-year program vocational high

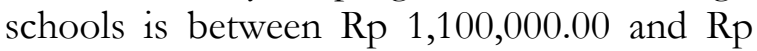
$5,000,000.00$, while the income of the graduates of three-year program vocational high schools is between $\mathrm{Rp} 1,000,000.00$ and $\mathrm{Rp}$ $2,500,000.00$. The income of the graduates of four-year program vocational high schools is aligned with the level of competence and performance.

\section{Conclusion and Suggestions}

Conclusion

In conclusion, the result of the research can be concluded as follows: (1) from the standpoint of school, the competence of the graduates of four-year program vocational high schools is superior in seven aspects, including: teamwork, discipline, tenacity, theoretical knowledge, confidence, creativity, and leadership; (2) from the standpoint of the employers of the graduates (DUDI), the graduates of four-year program vocational high schools are superior in eight aspects: discipline, tenacity, theoretical knowledge, practical skill, confidence, carefulness, creativity, and leadership; (3) from the standpoint of personal satisfaction of the jobs obtained, the graduates of four-year program vocational high schools expressed a higher level of satisfaction, specifically in terms of incomes; (4) the competence superiority of the graduates of four-year program vocational high schools resulted from a longer internship program (PKL) which provided students with richer skills as well as experience related to problemsolving activities in real daily work.

\section{Suggestions}

Based on the conclusion, some suggestions are proposed as follows: (1) reconsider the role of Internship program in the students learning process. For optimized results, there should be more systematic, effective and efficient development, execution, and evaluation in the internship program of the fouryear program vocational high schools; (2) for the internship program to be more efficient and effective, there should be unified evaluative efforts among all involved parties in schools and in business sector and industrial sector; (3) the result of the research shows that the graduates of the four-year program vocational high school are more superior than the graduates of the three-year program vocational high school in terms of working competence. Hence, there should be better appreciation for the graduates of the four-year program vocational high schools; (4) even though the graduates of the four-year program vocational high schools have sufficient skills to complete tasks presented individually, there should be more team-work-focused learning process for them.

\section{References}

Alisjahbana, A. S. (2014). Arah kebijakan dan program di bidang kependudukan, ketenagakerjaan, dan sumber daya manusia menghadapi globalisasi khususnya masyarakat ekonomi ASEAN. In Seminar Nasional Tantangan Kependudukan, Ketenagakerjaan, dan SDM Indonesia Menghadapi Globalisasi Khususnya Masyarakat Ekonomi ASEAN. Jakarta: Ikatan Praktisi dan Ahli Demografi Indonesia (IPADI).

Dewey, J. (1916). Democracy and education: An introduction to the philosophy of education. New York, NY: Dover Publication.

Kaufman, R., \& Susan, T. (1982). Evaluation without fear. London: New View Points.

Komariah, K. (2010). Memimpikan SMK di masa depan. In Seminar Nasional Prospek. Pengembangan Pendidikan Vokasional dalam Era Globalisasi (pp. 127-132). Bandung: Culinary Education Study Program, FPTK, Universitas Pendidikan Indonesia.

Law No. 20 of 2003 of Republic of Indonesia on National Education System (2003).

Pardjono, P., Sugiyono, S., \& Budiyono, A. (2015). Developing a model of competency certification test for vocational high school students. REiD (Research and Evaluation in Education), 1(2), 129145. 
https://doi.org/http://dx.doi.org/10.2 1831/reid.v1i2.6517

Ramayani, C., Aimon, H., \& Anis, A. (2012). Analisis produktivitas tenaga kerja dan pertumbuhan ekonomi Indonesia. Jurnal Kajian Ekonomi, 1(1). Retrieved from http:/ / ejournal.unp.ac.id/index.php/ek onomi/article/view/738

Regulation of the Minister of Education and Culture No. 20 of 2016 on the competence standard of primary and secondary education graduates (2016). Republic of Indonesia.
Stufflebeam, D. L., Madaus, G. F., \& Kellaghan, T. (2000). Evaluation models: Viempoints on educational and human services evaluation (2nd ed.). Boston, MA: Kluwer Academic Publishers.

Stufflebeam, D. L., \& Shinkfield, A. J. (1984). Systematic evaluation: A self-instructional guide to theory and practice. Dordrecht: Springer Netherlands.

Thompson, J. F. (1973). Foundations of vocational education: Social and philosophical concepts. Englewood Cliffs, NJ: PrenticeHall. 